\title{
Efikasi Guru dalam Mengembangkan Religiusitas Siswa Madrasah Ibtidaiyah Negeri Kelas Awal
}

\author{
Salamiah Sari Dewi' ${ }^{1}$, Hairul Anwar Dalimunthe ${ }^{1}$ \\ Psikologi, Universitas Medan Area Medan \\ DOI: 10.31004/obsesi.v6i4.2318
}

\begin{abstract}
Abstrak
Pengembangan religiusitas siswa didukung oleh efikasi guru. Penelitian ini bertujuan untuk menganalisis faktor-faktor yang berpengaruh terhadap efikasi guru yaitu kecerdasan emosional, harga diri terhadap pengembangan religiusitas siswa MIN kelas I sampai IV. Menggunakan metode kuantitatif korelasional dengan sampel 202 guru MIN di Kota Medan dan menggunakan teknik Purposive Sampling. Menggunakan teknik pengumpulan data berupa kuesioner dengan skala Likert dan alat ukur efikasi guru, kecerdasan emosi, dan harga diri secara offline. Teknik analisis data berupa statistik deskriptif AMOS 23.0, uji analisis jalur dan kausal linier. Hasil penelitian menunjukkan kecerdasan emosional tidak memiliki pengaruh signifikan terhadap pengembangan religiusitas siswa maupun efikasi guru dengan $\mathrm{p}>0,05$. Harga diri tidak memiliki pengaruh signifikan terhadap efikasi guru, demikian efikasi guru terhadap pengembangan religiusitas siswa dengan $p>0,05$. Harga diri memiliki pengaruh signifikan terhadap pengembangan religiusitas siswa dengan $p<0,05$. Pengembangan religiusitas siswa tidak hanya menjadi tanggungjawab guru, tetapi juga orangtua dan lingkungan.
\end{abstract}

Kata Kunci: kecerdasan emosional; religiusitas; harga diri; efikasi guru.

\begin{abstract}
The development of student religiosity is supported by teacher efficacy. This study aims to analyze the factors that influence teacher efficacy, namely emotional intelligence, self-esteem on the development of religiosity of MIN students in grades I to IV. Using the correlational quantitative method with a sample of 202 MIN teachers in Medan City and using the Purposive Sampling technique. Using data collection techniques in the form of a questionnaire with a Likert scale and offline teacher efficacy, emotional intelligence, and self-esteem measurement tools. Data analysis techniques in the form of descriptive statistics AMOS 23.0, path analysis test and linear causal. The results showed that emotional intelligence did not have a significant effect on the development of student religiosity and teacher efficacy with $\mathrm{p}>$ 0.05. Self-esteem has no significant effect on teacher efficacy, thus teacher efficacy on the development of student religiosity with $p>0.05$. Self-esteem has a significant effect on the development of student religiosity with $\mathrm{p}<0.05$. The development of student religiosity is not only the responsibility of the teacher, but also parents and the environment.
\end{abstract}

Keywords: emotional intelligence; religiosity; self esteem; teachers' efficacy.

Copyright (c) 2022 Salamiah Sari Dewi, Hairul Anwar Dalimunthe

$\triangle$ Corresponding author :

Email Address : salamiahsaridewi@staff.uma.ac.id (Medan, Indonesia)

Received 21 November 2021, Accepted 28 February 2022, Published 28 February 2022 


\section{PENDAHULUAN}

Religiusitas merupakan salah satu nilai karakter yang dijadikan sebagai sikap dan perilaku yang patuh dalam melaksanakan ajaran agama yang dianut, toleran terhadap pelaksanaan ibadah agama lain, dan hidup rukun dengan pemeluk agama lain (Ningsih, Praseyto \& Hasanah, 2022). Karakter religius ini sangat dibutuhkan oleh siswa dimulai dari usia sekolah dasar dalam menghadapi perubahan zaman dan degradasi moral seperti saat ini. Hal ini dikarenakan maraknya tindakan-tindakan tidak terpuji seperti degradasi moral, kekerasan, beragam konflik dan meluasnya kesenjangan sosial antar masyarakat yang merusak citra bangsa Indonesia sebagai bangsa yang bermartabat. Fakta yang muncul di lapangan adalah terjadinya tindak perundungan tidak hanya terhadap antarkelompok agama tertentu, tetapi juga di dalam kelompok agama itu sendiri seperti yang terjadi pada konflik antar umat beragama di Aceh tahun 2019, konflik Poso tahun 2000, konflik Tanjung Balai tahun 2016, konflik Sampang tahun 2004 dan konflik Papua tahun 2018. Hal ini disebabkan oleh memudarnya nilai-nilai religiusitas bangsa Indonesia yang selama ini dianggap sebagai bangsa yang religius dan menjunjung tinggi nilai-nilai agama dalam kehidupan (Dewi, 2021).

Munculnya stereotype satu kelompok terhadap kelompok lain yang berbeda agama biasanya menjadi pemicu konflik antar umat beragama yang diikuti oleh upaya saling serang, saling membunuh, membakar rumah-rumah ibadah dan tempat-tempat bernilai bagi masingmasing pemeluk agama (Yunus, 2014). Tidak hanya itu, munculnya kekuatan-kekuatan baru dalam satu agama yang sama yang semakin menyuburkan gerakan-gerakan baru dalam agama bahkan menjadi penyebab konflik internal agama yang sangat mencolok, karena orang atau kelompok tertentu dalam suatu agama selalu berupaya menafsirkan kembali ajaran agamanya menurut pemahamannya masing-masing. Hal itu yang membuat kelompok tersebut merasa paling benar dalam beragama, sehingga dengan mudah menghina dan merendahkan orang lain diluar kelompoknya walaupun memiliki agama yang sama. Dampak terburuk dari konflik-konflik tersebut adalah hilangnya rasa toleran dalam kehidupan beragama, berbangsa dan bernegara (Yunus, 2014). Padahal, sebagai bangsa yang menjunjung tinggi nilai religius dalam kehidupan, hendaklah hidup saling berdampingan dan menghargai satu sama lain. Tetapi keyataannya, masih banyak peristiwa yang tidak mencerminkan nilai religius justru marak terjadi, bahkan dilakukan oleh orang-orang yang merasa paling religius.

Religiusitas adalah suatu cara pandang dari buah pikiran (mind of sense) seseorang mengenai agamanya serta bagaimana individu tersebut menggunakan keyakinan atau agamanya dalam kehidupan sehari-hari (Earnshaw, t.t.). Sumber jiwa keagamaan itu adalah rasa ketergantungan yang mutlak (dependency of absolute), adanya ketakutan-ketakutan akan ancaman dari faktor eksternal serta keyakinan individu tentang segala keterbatasan dan kelemahannya (Ancok dkk., 2001). Religiusitas yang rendah pada siswa mengakibatkan hubungan yang kurang harmonis dengan sesama temannya, merasa paling benar dalam kegiatan agamanya walaupun memiliki agama yang sama dan saling menghujat antar sesama, bahkan dapat mengakibatkan terjadinya kenakalan remaja dan cenderung tidak dapat menghindari perbuatan yang dilarang agama, sehingga melakukan perbuatan kriminal (Hasanah \& Fadlilah, 2018).

Menurut (Umar, 2019), lingkungan sekolah adalah salah satu lingkungan yang sangat berperan penting dalam pembentukan religiusitas anak. Sehingga, guru diharapkan mampu dalam mengembangkan religiusitas siswanya. Dalam memberikan pendidikan kepada siswa, seorang guru hendaklah memiliki efikasi dalam dirinya. Seseorang akan mampu menggunakan potensi dirinya secara optimal apabila efikasi diri mendukungnya, termasuk dalam mengajar siswa untuk mengembangkan religiusitasnya. (Umar, 2019) menambahkan bahwa efikasi guru yang tinggi dapat menyukseskan segala visi, misi dan tujuan sekolah. Namun, efikasi guru yang rendah dapat mengakibatkan guru mengalami kesulitan dalam mengajar, beresiko mengalami stres kerja, dan memiliki kepuasan kerja yang rendah. 
Guru yang memiliki tanggungjawab yang besar terhadap upaya mengembangan religiusitas siswanya, memiliki faktor-faktor yang mempengaruhi efikasinya dalam mendidik siswa. Faktor-faktor personal yang memengaruhi efikasi guru (dalam Erawati, 2012) diketahui berupa spiritualitas dan konsep diri interdependensi (Houkamau dkk., 2021) kecerdasan emosional (Jennett dkk., 2003), dan harga diri (Huang dkk., 2007). Kecerdasan emosi adalah suatu kemampuan umum dari seseorang dalam hal bagaimana dia memecahkan masalah hidupnya sehari-hari. Orang yang memiliki kecerdasan emosional yang baik akan mampu menghadapi tantangan dan menjadi manusia yang penuh tanggung jawab, produktif dan optimis dalam menghadapi dan menyelesaikan masalah, dimana hal-hal tersebut sangat dibutuhkan di dalam lingkungan kerja (Darmadi, 2020). Guru adalah role model yang menjadi panutan. Seorang guru yang dikatakan memiliki kecerdasan emosional yang baik jika mampu mengendalikan diri. Dalam keadaan emosi yang terkendali akan memudahkan Guru Pintar memunculkan motivasi untuk membangun keadaan emosional yang stabil. Keadaan emosi yang stabil memudahkan Guru Pintar untuk terus belajar serta mengembangkan kemampuan diri. Pentingnya kecerdasan emosional adalah untuk memberikan pemahaman diri sendiri dan orang lain secara efektif, berhubungan baik dengan orang lain, dan beradaptasi dengan lingkungan sekitar agar lebih mudah beradaptasi dan menghadapi tantangan yang selalu berubah-ubah, termasuk tantangan terhadap konflik antar agama yang sering terjadi. Sehingga, tidak hanya kecerdasan emosionalnya saja, tetapi guru juga harus berupaya mengembangkan karakter religius pada siswanya (Oktiva, 2021).

Demikian juga dengan harga diri guru. Harga diri guru mempengaruhi prestasi akademik siswanya. Harga diri guru yang tinggi mampu menciptakan suasana belajar yang kondusif dan inovatif. Sebagai guru yang memiliki harga diri, maka guru akan merasa bertanggungjawab untuk membimbing dan mengarahkan siswaya menjadi lebih baik dan memiliki karakter yang positif khususnya karakter religius (Bada \& Hasan, 2021). Dan guru yang mempunyai harga diri (self esteem) tinggi akan membangkitkan rasa percaya dirinya, merasa mampu dan yakin akan dirinya, merasa berguna, serta merasa bahwa keberadaannya dibutuhkan (Damayanti, t.t.).

Inilah mengapa efikasi guru yang dipengaruhi oleh kecerdasan emosional dan harga diri dalam mengembangkan religiusitas siswa menjadi penting untuk diteliti. Hal ini dilakukan guna membuktikan bagaimana faktor-faktor tersebut memberikan pengaruh terhadap efikasi guru dalam mengembangkan religiusitas siswa, khususnya bagi guru-guru yang mengajar di sekolah berbasis agama, dalam hal ini Madrasah Ibtidaiyah Negeri di kota Medan.

\section{METODOLOGI}

Penelitian ini menggunakan metode kuantitatif korelasional. Penelitian ini bertujuan untuk menganalisis faktor-faktor yang berpengaruh terhadap efikasi guru yaitu kecerdasan emosional dan harga diri dalam mengembangkan religiusitas siswa MIN dikota Medan. Teknik pengumpulan data dalam penelitian yaitu angket atau kuesioner dengan skala Likert menggunakan alat ukur efikasi guru, kecerdasan emosional dan harga diri yang dibagikan secara offline.

Penelitian ini dilakukan di 7 Madrasah Ibtidaiyah Negeri yang ada di kota Medan yaitu MIN 3 Medan, MIN 6 Medan, MIN 7 Medan, MIN 8 Medan, MIN 9 Medan, MIN 11 Medan, dan MIN 12 Medan. Sampel pada penelitian ini adalah 202 guru MIN mulai dari kelas I sampai IV menggunakan Purposive Sampling. Purposive sampling menurut (Sugiyono, 2011) adalah teknik pengambilan sampel dengan pertimbangan tertentu.

Peneliti menggunakan statistik deskriptif dengan SPSS dan Model Persamaan Struktural atau Structural Equation Model, yang dioperasikan melalui Program Analisis Momen Struktur dengan langkah-langkah sebagai berikut. Pertama, Analisis Model Pengukuran (Measurement Model): Analisis model pengukuran (measurement model) mengandung tiga langkah yaitu uji kecocokan keseluruhan, analisis validitas dan 
analisis reliabilitas. Kedua, Analisis Model Struktural (Structural Model): adapun pengujian-pengujian ini dilakukan secara dua macam, yaitu uji kesesuaian model dan uji kausalitas dengan langkah-langkah: pengembangan model berdasar teori, menyusun diagram jalur yang menunjukkan hubungan kausalitas, menerjemahkan diagram jalur ke Persamaan Struktural, memilih jenis matriks input dan estimasi model yang diusulkan, menilai kriteria Goodness of Fit, evaluasi Multivariat Outler, analisis Normalitas dan Multikolinearitas dan Singularity. Ketiga Kesesuaian Model : Pengujian kesesuaian model penelitian digunakan untuk menguji seberapa baik tingkat goodness of fit dari model penelitian. Keempat, Modifikasi Model (Jika tidak memenuhi asumsi SEM). Kelima, Interpretasi (Hipotesis dan Hubungan Kausal), Keenam, analisis persyaratan.

Uji Hipotesis Untuk menguji hipotesis penelitian teknik analisis varians digunakan analisis varians univariat disajikan pada tabel 1.

Tabel 1. Analisis varians univariat

\begin{aligned} & \hline Hipotesis \multicolumn{1}{c}{ Keterangan } \\ & \hline $\mathrm{Ha}_{1}: \beta_{1} \neq 0 \begin{array}{l}\text { Terdapat pengaruh signifikan kecerdasan emosional terhadap } \\ \text { pengembangan religiusitas siswa MIN di kota Medan }\end{array} \\ & \mathrm{Ha}_{2}: \beta_{2} \neq 0 \begin{array}{l}\text { Terdapat pengaruh signifikan harga diri terhadap pengembangan } \\ \text { religiusitas siswa MIN di kota Medan }\end{array} \\ & \mathrm{Ha}_{3}: \beta_{3} \neq 0 \begin{array}{l}\text { Terdapat pengaruh signifikan kecerdasan emosional terhadap efikasi guru } \\ \text { MIN di kota Medan }\end{array} \\ & \mathrm{Ha}_{4}: \beta_{4} \neq 0 \begin{array}{l}\text { Terdapat pengaruh signifikan harga diri terhadap efikasi guru MIN di } \\ \text { kota Medan } \\ \mathrm{Ha}_{5}: \beta_{5} \neq 0\end{array} \\ & \begin{array}{l}\text { Terdapat pengaruh signifikan efikasi guru terhadap pengembangan } \\ \text { religiuisitas siswa MIN di kota Medan }\end{array} \\ &$\hline\end{aligned}

\section{HASIL DAN PEMBAHASAN}

\section{Uji Model Instrumen Pengukuran \\ Efikasi Guru}

Skala Efikasi Guru terdiri dari 34 butir awal yang tersebar dalam 3 aspek yaitu Hubungan dengan siswa (14 butir), Strategi Intruksional (12 butir), dan Manajemen kelas (8 butir). Adapun indeks ketepatan model pengukuran awal dan setelah dimodifikasi dapat dilihat pada tabel 2.

Tabel 2. Indeks Ketepatan Model pada Pengukuran Efikasi Guru

\begin{tabular}{lclcl}
\hline Parameter & $\begin{array}{r}\text { Model } \\
\text { Awal }\end{array}$ & Keterangan & $\begin{array}{c}\text { Model Setelah } \\
\text { Modifikasi }\end{array}$ & Keterangan \\
\hline Chi-square & 2100,735 & - & 75,792 & - \\
Probability & 0,000 & Tidak fit & 0,001 & Tidak fit \\
CMIN/DF & 4,009 & Tidak fit & 1,849 & Fit \\
CFI & 0,471 & Tidak fit & 0,944 & Fit \\
TLI & 0,434 & Tidak fit & 0,925 & Fit \\
GFI & 0,560 & Tidak fit & 0,935 & Fit \\
RMSEA & 0,122 & Tidak fit & 0,065 & Fit \\
\hline Cut-off criteria $=(1)$ Probability $\geq 0,05,(2)$ CMIN/DF $\leq 2,(3)$ CFI $\geq 0,90,(4)$ TLI \\
\multicolumn{4}{c}{$\geq 0,90,(5)$ GFI $\geq 0,90$, dan (6) RMSEA $\leq 0,08}$. \\
\end{tabular}

Berdasarkan Tabel 1, model pengukuran awal memiliki nilai chi-square $(2100,735)$ yang jauh berbeda dengan model setelah dimodifikasi $(75,792)$ dengan probabilitas keduanya di bawah 0,01. Namun, nilai chi-square mudah terpengaruh oleh jumlah sampel sehingga sulit dipercaya untuk dapat dijadikan patokan dalam menilai model fit atau tidak, sehingga pada 
penelitian kali ini indeks chi-square dan probabilitas tidak digunakan dalam mengambil keputusan. Nilai CMIN/DF setelah modifikasi berada pada nilai 1,849 yang memenuhi syarat kriteria fit. Berdasarkan parameter CFI, TLI, dan GFI model yang telah dimodifikasi terindikasi sebagai model yang dapat diterima karena memiliki nilai $\geq 0,90$. Sementara itu, berdasarkan RMSEA nilai 0,065 terindikasi sebagai nilai fit dan dapat diterima karena memenuhi indeks kriteria $\leq 0,08$. Adapun perihal model yang telah dimodifikasi dapat dilihat pada gambar 1.

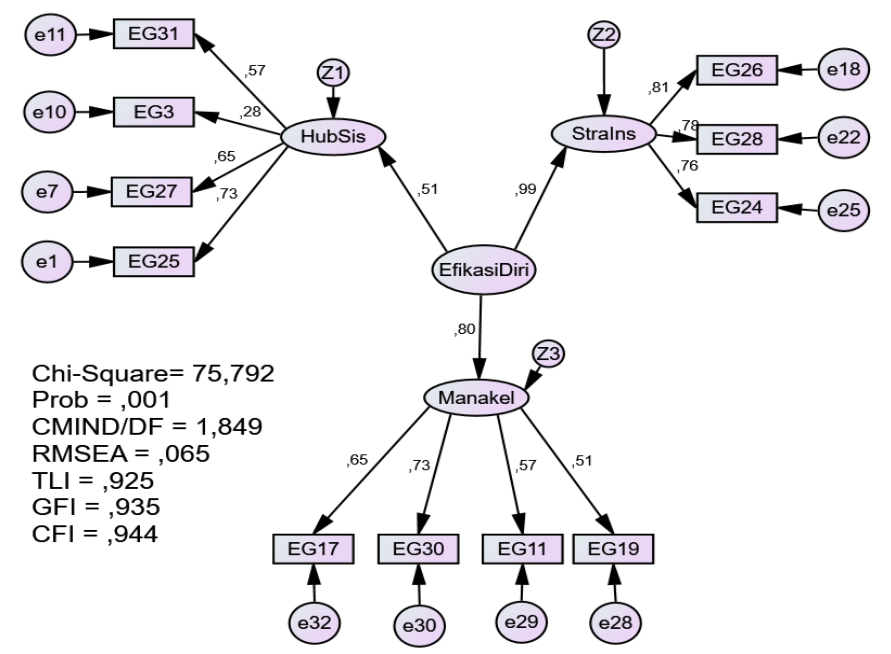

Gambar 1. Model Pengukuran Efikasi Diri Setelah Modifikasi

Factor loading merupakan indeks yang menyunjukkan sebera besar butir mampu menggambarkan sebuah konstruk pengukuran, sehingga penting untuk diperhatikan. Berdasarkan gambar 1 diketahui bahwa hampir seluruh butir memiliki nilai loading faktor di atas 0,3. Pada aspek Hubungan dengan Siswa terdiri dari 4 butir dengan factor loading bergerak antara 0,282 hingga 0,728, aspek Strategi Instruksional terdiri dari 3 butir dengan factor loading berkisar antara 0,763 hingga 0,814, dan pada aspek Manajemen Kelas memiliki 4 butir dengan factor loading bergerak antara nilai 0,513 hingga 0,728 .

\section{Pengembangan Religiusitas Siswa}

Skala Pengembangan Religiusitas Siswa terdiri dari empat 52 butir awal yang termuat dalam 4 aspek yaitu aspek Aqidah (7 butir), Ibadah (11 butir), Amal (25 Butir), dan aspek Ihsan (9 butir). Indeks ketepatan model pengukuran Pengembangan Religiusitas Siswa dapat dilihat pada tabel 3.

Tabel 3. Indeks Ketepatan Model pada Pengukuran Religiusitas

\begin{tabular}{ccccc}
\hline Parameter & $\begin{array}{c}\text { Model } \\
\text { Awal }\end{array}$ & Keterangan & $\begin{array}{c}\text { Model Setelah } \\
\text { Modifikasi }\end{array}$ & Keterangan \\
\hline Chi-square & 4306,315 & - & 168,676 & - \\
Probability & 0,000 & Tidak fit & 0,000 & Tidak fit \\
CMIN/DF & 3,391 & Tidak fit & 1,687 & Fit \\
CFI & 0,477 & Tidak fit & 0,941 & Fit \\
TLI & 0,454 & Tidak fit & 0,929 & Fit \\
GFI & 0,523 & Tidak fit & 0,914 & Fit \\
RMSEA & 0,109 & Tidak fit & 0,058 & Fit \\
\hline Cut-off criteria $=(1)$ Probability $\geq 0,05,(2)$ CMIN/DF $\leq 2,(3)$ CFI $\geq 0,90,(4)$ \\
\multicolumn{5}{c}{ TLI $\geq 0,90,(5)$ GFI $\geq 0,90$, dan (6) RMSEA $\leq 0,08}$. \\
\end{tabular}

Berdasarkan Tabel 3, model pengukuran awal religiusitas memiliki nilai chi-square 4306,315 , sedangkan setelah dimodifikasi nilai chi-squarenya turun menjadi 168,675 . Nilai probabiliti untuk kedua model pun dikatehui berada di bawah 0,01, walaupun demikian sama 
halnya dengan model pengukuruan efikasi diri, pada model pengukuran religiusitas nilai chisquare dan probability tidak digunakan sebagai kriteria dalam menentukan sebuah model fit atau tidak. Nilai CMIN/DF pada model pengukuran setelah modifikasi yang berada pada nilai 1,687 mengindikasikan bahwa model fit berdasarkan kriteria tersebut. Adapun untuk model yang telah dimodifikasi menunjukkan bahwa model tersbut terindikasi fit. Model yang telah diidentifikasi dapat dilihat pada gambar 2.

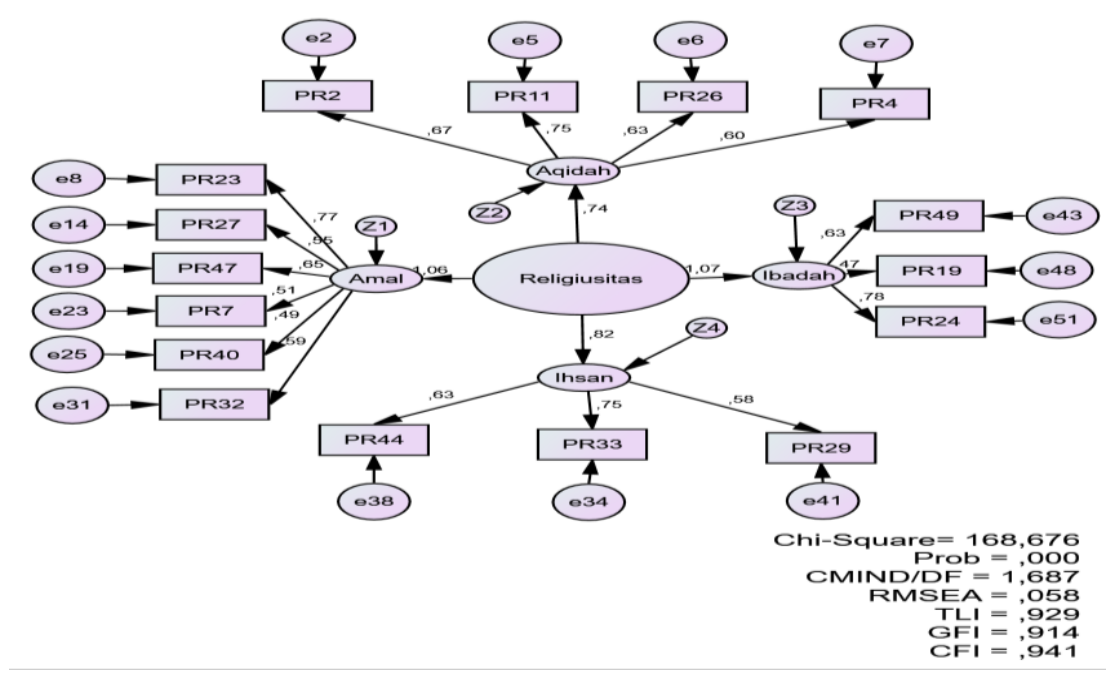

Gambar 2. Model Pengukuran Religiusitas Siswa Setelah Modifikasi

Berdasarkan gambar 2 didapatkan informasi bahwa seluruh butir memiliki nilai loading faktor di atas 0,3. Pada aspek Amal terdapat 6 butir dengan factor loading yang bergerak antara 0,489 sampai 0,774, aspek Aqidah terdiri dari 4 butir dengan factor loading berkisar antara 0,601 hingga 0,752, aspek Ihsan dengan 3 butir yang factor loading-nya bergerak antara 0,577 sampai 0,747, serta aspek Ibadah dengan 3 butir dengan factor loading berkisar dari 0,474 hingga 0,780.

\section{Kecerdasan Emosional}

Skala kecerdasan emosi terdiri dari 5 aspek dengan 40 jumlah keseluruhan butir. Secara detail butir-butir tersebut tersebar pada aspek mengenali emosi diri dengan 4 butir, aspek mengelola emosi dengan 13 butir, memotivasi diri sendiri dengan 8 butir, pada aspek mengenali emosi orang lain dengan 3 butir, serta pada aspek membina hubungan dengan orang lain yaitu 12 butir. Sementara itu, untuk indeks ketepatan model kecerdasan emosi baik awal dan setelah dimodifikasi dapat dilihat pada tabel 3.

Tabel 4. Indeks Ketepatan Model pada Pengukuran Kecerdasan Emosional

\begin{tabular}{lllll}
\hline Parameter & $\begin{array}{r}\text { Model } \\
\text { Awal }\end{array}$ & Keterangan & $\begin{array}{r}\text { Model } \\
\text { Modifikasi }\end{array}$ & Keterangan \\
\hline Chi-square & 2360,145 & - & 145,005 & - \\
Probability & 0,000 & Tidak fit & 0,000 & Tidak fit \\
CMIN/DF & 3,211 & Tidak fit & 1,706 & Fit \\
CFI & 0,540 & Tidak fit & 0,923 & Fit \\
TLI & 0,512 & Tidak fit & 0,904 & Fit \\
GFI & 0,593 & Tidak fit & 0,911 & Fit \\
RMSEA & 0,105 & Tidak fit & 0,059 & Fit \\
\hline Cut-off criteria $=(1)$ Probability $\geq 0,05,(2)$ CMIN/DF $\leq 2,(3)$ CFI $\geq 0,90,(4)$ TLI $\geq$ \\
\multicolumn{2}{c}{ 0,90, (5) GFI $\geq 0,90$, dan (6) RMSEA $\leq 0,08}$.
\end{tabular}


Berdasarkan Tabel 4, model pengukuran kecerdasan emosi awal memiliki nilai chisquare 2360,145 yang di mana hal ini cukup besar dengan model setelah dimodifikasi 145,005 yang keduanya memiliki probabiliti di bawah 0,01. Berdasarkan nilai CMIN/DF setelah modifikasi berada pada nilai 1,706 yang memenuhi syarat kriteria fit. Adapun perihal model yang telah dimodifikasi dapat dilihat pada gambar gambar 3 .
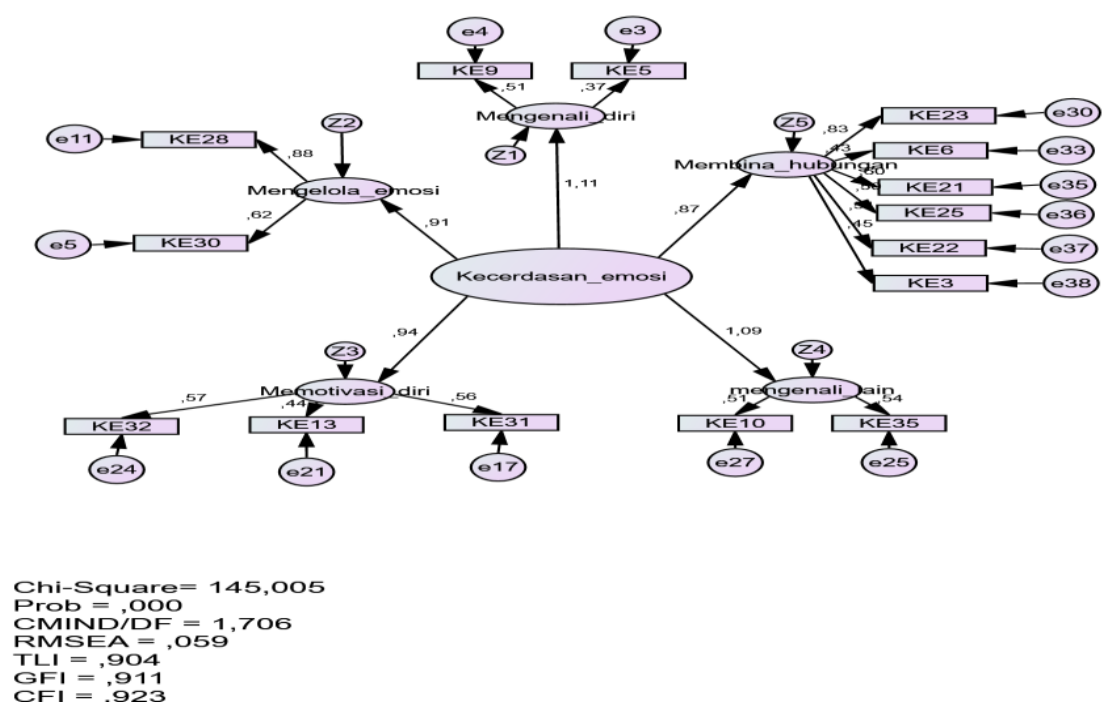

\section{Gambar 3. Model Pengukuran Kecerdasan Emosi Setelah Modifikasi}

Berdasarkan gambar 3 diketahui bahwa seluruh butir model pengukuran kecerdasan emosi memiliki nilai factor loading di atas 0,3. Pada aspek membina hubungan dengan orang lain terdiri dari 6 butir dengan factor loading berkisar antara 0,432 hingga 0,825, aspek memotivasi diri sendiri dengan factor loading antara 0,444 hingga 0,566, aspek mengenali emosi diri dengan factor loading berkisar antara 0,617 hingga 878, aspek mengenali emosi orang lain dengan factor loading 0,617 hingga 0,878, serta aspek mengelola emosi dengan factor loading 0,617 hingga 0,878 .

\section{Harga Diri}

Skala harga diri terdiri dari empat 40 butir yang termuat dalam 4 aspek yaitu aspek Kekuatan (10 butir), Keberartian (18 butir), Kebajikan (4 Butir), dan aspek Kompetensi (8 butir). Indeks ketepatan model pengukuran harga diri dapat dilihat pada tabel 5.

Tabel 5. Indeks Ketepatan Model pada Pengukuran Harga Diri

\begin{tabular}{lclll}
\hline Parameter & $\begin{array}{c}\text { Model } \\
\text { Awal }\end{array}$ & Keterangan & $\begin{array}{r}\text { Model } \\
\text { Modifikasi }\end{array}$ & Ketelah \\
& 2443,785 & - & 39,785 & - \\
Chi-square & 0,000 & Tidak fit & 0,001 & Tidak fit \\
Probability & 3,320 & Tidak fit & 2,340 & Tidak Fit \\
CMIN/DF & 0,492 & Tidak fit & 0,957 & Fit \\
CFI & 0,461 & Tidak fit & 0,929 & Fit \\
TLI & 0,570 & Tidak fit & 0,951 & Fit \\
GFI & 0,107 & Tidak fit & 0,082 & Marginal \\
RMSEA & Fit \\
\hline Cut-off criteria $=(1)$ & Probability $\geq 0,05,(2)$ CMIN/DF $\leq 2,(3)$ CFI $\geq 0,90,(4)$ TLI $\geq$ \\
\multicolumn{2}{c}{ 0,90, (5) GFI $\geq 0,90$, dan (6) RMSEA $\leq 0,08}$.
\end{tabular}

Berdasarkan Tabel 7, model pengukuran awal harga diri memiliki nilai chi-square 2443,785, sedangkan setelah dimodifikasi nilai chi-squarenya turun menjadi 39,785. Nilai probabiliti untuk kedua model pun berada di bawah 0,01, walaupun demikian sama halnya 
DOI: $10.31004 /$ obsesi.v6i4.2318

dengan model pengukuruan lainnya, pada model pengukuran religiusitas nilai chi-square dan probability tidak digunakan sebagai kriteria dalam menentukan sebuah model fit atau tidak. Nilai CMIN/DF pada model pengukuran awal dan setelah modifikasi yang berada pada nilai $\geq 2,0$ mengindikasikan bahwa model tidak fit berdasarkan kriteria tersebut. Model pengukuran harga diri yang telah diidentifikasi dapat dilihat pada gambar 4 .
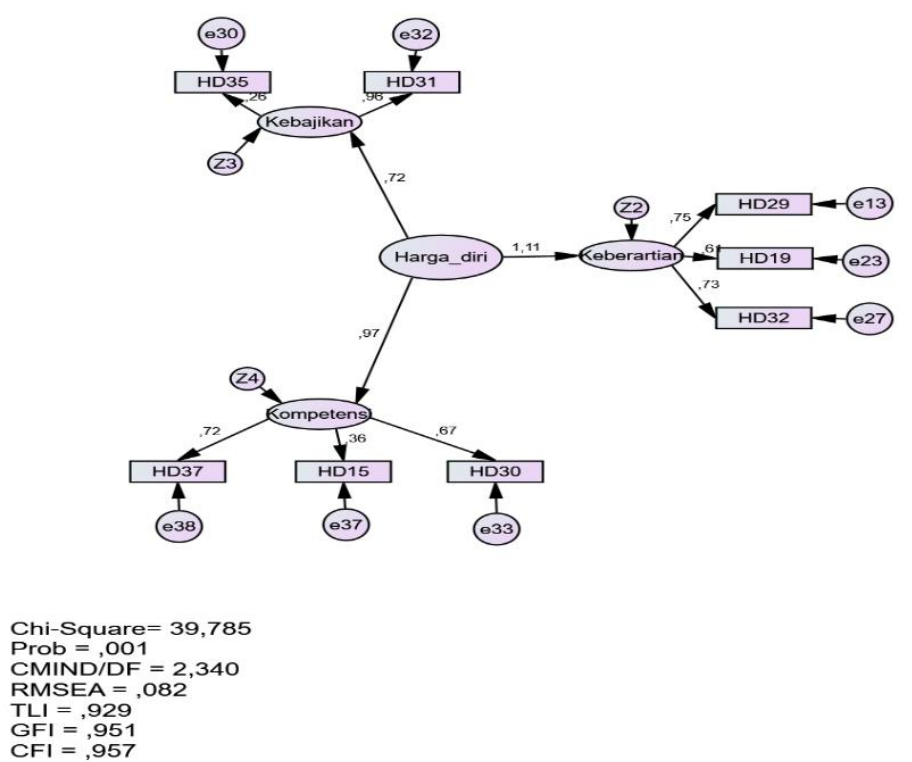

Gambar 4. Model Pengukuran Harga Diri Setelah Modifikasi

Berdasarkan gambar 4 didapatkan informasi bahwa hampir seluruh butir memiliki nilai factor loading di atas 0,3 kecuali pada butir HD35 yang memiliki factor loading 0,264, namun hal ini dapat ditorerir karena butir ini terindikasi signifikan dan pada kasusnya jika butir ini digugurkan maka aspek kebajikan tidak dapat dilibatkan pada model pengukuran karena tidak memiliki indikator pengukuran yang signifikan lainnya, selain itu juga butir dengan factor loading di bawah 0,3 dapat tetap diterima asalkan memenuhi syarat tertentu.

\section{Reliabilitas Model Pengukuran}

Berdasarkan paramenter CR diketahui bahwa seluruh instrumen pengukuran memiliki nilai reliabilitas di atas 0,7 dengan nilai yang bergerak dari 0,897 hingga 0,945, sedangkan berdasarkan parameter AVE diketahui rentang indeks AVE instrumen pengukuran bergerak dari 0,421 sampai 0,547 yang dimana terdapat satu instrumen pengukuran yang memiliki nilai AVE lebih kecil daripada 0,5 yaitu instrumen pengukuran kecerdasan emosi, hal ini mengartikan bahwa indikator pada instrumen pengukuran memiliki varian yang kurang begitu besar, namun karena model pengukuran terindikasi fit dan reliabilitas pengukuran terinindikasi baik, instrumen pengukuran tetap diikutsertakan dalam model structural. Hasil perhitungan CR dan AVE dapat di lihat pada tabel 5.

Tabel 6. Reliabilitas Instrumen Pengukuran

\begin{tabular}{llll}
\hline No. & Variabel & CR & AVE \\
\hline 1 & Efikasi Guru & 0.926 & 0.546 \\
2 & Religiusitas Siswa & 0.945 & 0.522 \\
3 & Kecerdasan Emosi & 0.912 & 0.421 \\
4 & Harga Diri & 0.897 & 0.547 \\
\hline
\end{tabular}




\section{Evaluasi Asumsi Model Struktural \\ Evaluasi Outlier}

Berdasarkan hasil analisis outlier yang dilakukan di Amos, dengan minimal Mahalanobis Distance $(1154 ; 0,05)$ yaitu sebesar 1234,142 diketahui bahwa tidak ada partisipan yang memiliki nilai Mahalanobis Distance diatas 1234,142, sehingga dapat dismpulkan bahwa tidak ada outlier pada penelitian ini.

\section{Normalitas Multivariate}

Pada penelitian ini nilai c.r. multivariatnya adalah 83,744 , sehingga dapat simpulkan bahwa secara multivariat model tidak terdistribusi normal.

\section{Normalitas Multivariate}

Pada penelitian ini diketahui bahwa detereminan matriks kovarians sampel bernilai 0,00 sehingga dapat disimpulkan bahwa tidak terdapat indikasi multikolinearitas dan singularitas pada penelitian model structural.

\section{Uji Model Struktural \\ Indeks Ketepatan Model}

Adapun indeks ketepatan model penelitian awal dan setelah dimodifikasi dapat dilihat pada tabel 7.

Tabel 7. Indeks Ketepatan Model pada Model Penelitian

\begin{tabular}{|c|c|c|c|c|}
\hline Parameter & Model Awal & Keterangan & Model Setelah Modifikasi & Keterangan \\
\hline Chi-square & 2900,519 & - & 406,983 & - \\
\hline Probability & 0,000 & Tidak fit & 0,000 & Tidak fit \\
\hline CMIN/DF & 2,513 & Tidak fit & 1,577 & Fit \\
\hline CFI & 0,661 & Tidak fit & 0,910 & Fit \\
\hline TLI & 0,640 & Tidak fit & 0,895 & Marginal Fit \\
\hline GFI & 0,645 & Tidak fit & 0,863 & Marginal Fit \\
\hline RMSEA & 0,087 & Marginal fit & 0,054 & Fit \\
\hline
\end{tabular}

Berdasarkan Tabel 5, model penelitian awal memiliki nilai chi-square $(2900,519)$ yang jauh berbeda dengan model setelah dimodifikasi $(406,983)$ dengan probabilitas keduanya di bawah 0,01 . Sama halnya pada model pengukuran, nilai chi-square yang mudah terpengaruh oleh jumlah sampel menyebabkan kriteria ini sulit dipercaya untuk dijadikan patokan dalam menilai model fit atau tidak, sehingga pada indeks chi-square dan probabilitas tidak digunakan dalam mengambil keputusan. Nilai CMIN/DF setelah modifikasi berada pada nilai 1,577 yang memenuhi syarat kriteria fit. Berdasarkan parameter CFI model penelitian yang telah dimodifikasi terindikasi sebagai model yang dapat diterima karena memiliki nilai $\geq 0,90$, sedangkan berdasarkan parameter TLI dan GFI model diterima dengan kriteria yang berada pada batas penerimaan minimum, yaitu diantaraa 0,80 hingga 0,90. Sementara itu, berdasarkan RMSEA model awal menunjukkan bahwa model teridnikasi marginal fit, namun setelah modifikasi nilai RMSEA menjadi 0,054 yang dimana hal ini menandakan bahwa model terindikasi fit dan dapat diterima karena memenuhi indeks kriteria $\leq 0,08$. Model penelitian yang telah diidentifikasi dapat dilihat pada gambar 5 .

Berdasarkan gambar 5 didapatkan informasi bahwa hampir seluruh butir memiliki nilai factor loading di atas 0,3 kecuali pada butir HD35 yang memiliki factor loading 291, namun hal ini dapat ditorerir karena butir ini terindikasi signifikan dan pada kasusnya jika butir ini digugurkan maka aspek kebajikan tidak dapat dilibatkan pada model penelitian karena tidak memiliki indikator pengukuran yang signifikan lainnya, selain itu juga butir dengan factor 
loading di bawah 0,3 dapat tetap diterima asalkan memenuhi syarat tertentu. Variabel pengukuran pada model penelitian setelah modifikasi cukup banyak mengalami perubahan, diantaranya digugurkannya aspek kompetensi pada variabel harga diri, digugurkannya aspek mengenal emosi orang lain pada variabel kecerdasan emosi, dieliminasinya aspek manajemen kelas pada variabel efikasi guru, dan dikeluarkannya aspek ihsan pada variabel religiusitas siswa. Aspek-aspek tersebut terpaksa digugurkan karena aspek maupun butirbutir yang mewakili aspek tersebut memiliki korelasi eror yang tinggi antaritem atau antaraspek.

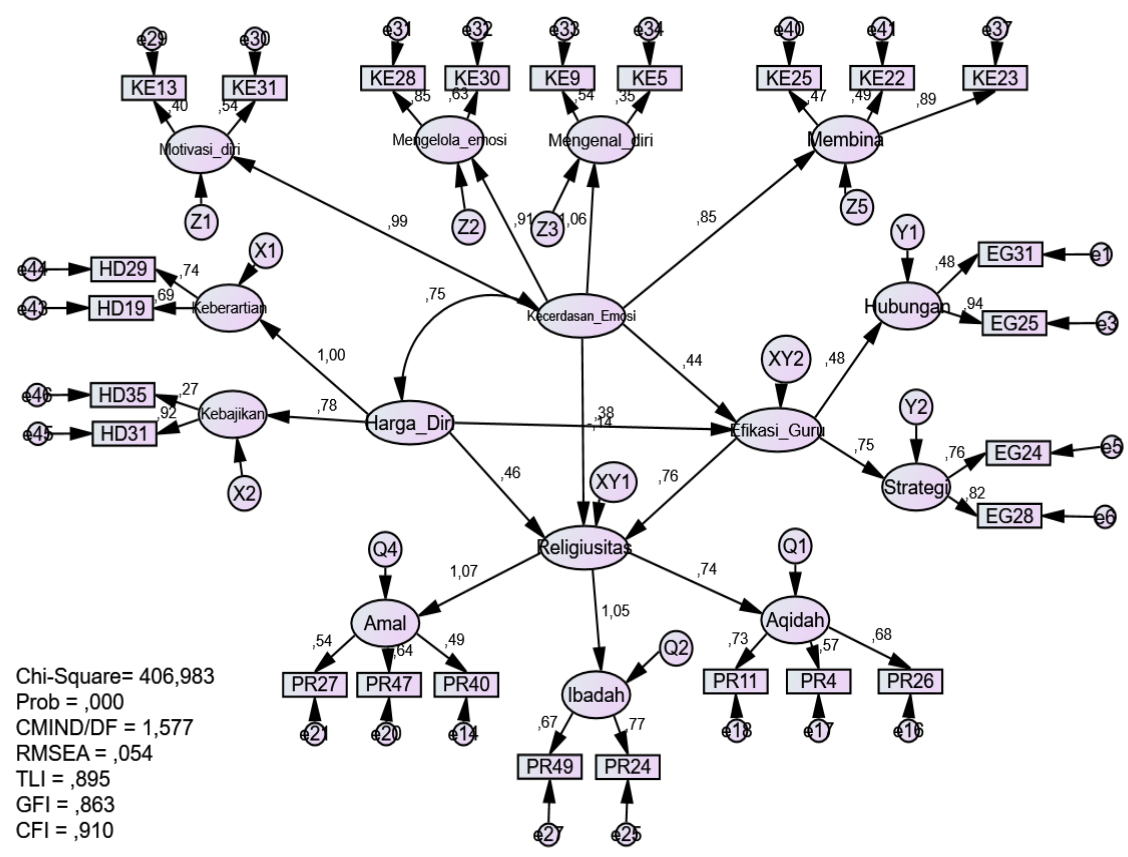

Gambar 5. Model Penelitian Modifikasi

\section{Uji Hipotesis}

Model penelitian yang fit telah di dapatlkan, kemudian berdasarkan model tersebut diidentifikasi pengaruh variabel-variabel independen guna menjawab hipotesis yang telah di tentukan oleh peneliti. Pengaruh variabel dapat dilihat pada gambar 6 .

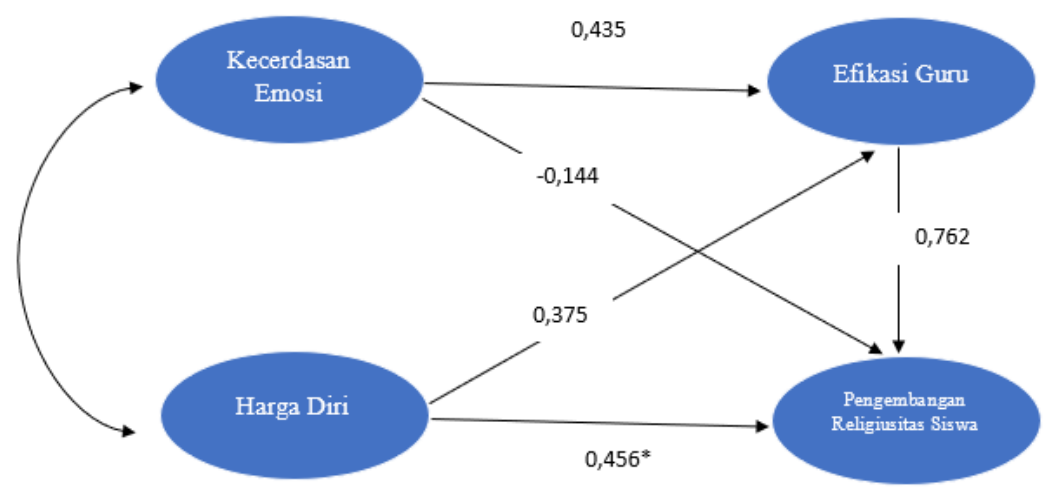

Gambar 6. Besar Pengaruh Antarvariabel Berdasarkan Model Hipotesis

\section{Keterangan:}

Hipotesis 1: Terdapat pengaruh signifikan kecerdasan emosi terhadap pengembangan religiusitas siswa MIN di kota Medan. Hasil analisis menunjukkan bahwa kecerdasan 
emosi memiliki pengaruh negatif terhadap pengembangan religiusitas siswa dengan beta $-0,144$. Namun, walaupun demikian pengaruh tersebut tidaklah signifikan $(p>0,05)$, sehingga dapat disimpulkan bahwa kecerdasan emosi tidak memilki pengaruh yang signifikan terhadap pengembangan religiusitas siswa MIN di kota Medan. Dengan demikian hipotesis pertama ditolak.

Hipotesis 2: Terdapat pengaruh signifikan harga diri terhadap pengembangan religiusitas siswa MIN di kota Medan. Hasil analisis menunjukkan bahwa harga diri memiliki pengaruh yang signifikan terhadap pengembangan religiusitas siswa dengan. Hal ini dibuktikan dengan nilai beta 0,456 dengan signifikasinsi $p<0,05$. Oleh karena itu, dapat disimpulkan bahwa hipotesis kedua diterima.

Hipotesis 3: Terdapat pengaruh signifikan kecerdasan emosi terhadap efikasi guru MIN di kota Medan. Hasil analisis menunjukkan bahwa kecerdasan emosi memiliki pengaruh terhadap efikasi guru dengan beta sebesar 0,435. Namun, sayangnya pengaruh tersebut tidaklah signifikan ( $p>0,05)$, sehingga dapat disimpulkan bahwa kecerdasan emosi tidak memilki pengaruh yang signifikan terhadap efiaksi guru MIN di kota Medan. Dengan demikian hipotesis ketiga ditolak.

Hipotesis 4: Terdapat pengaruh signifikan harga diri terhadap efikasi guru MIN di kota Medan. Hasil analisis menunjukkan bahwa harga diri memiliki pengaruh terhadap efikasi guru dengan beta sebesar 0,375. Namun, pengaruh tersebut tidaklah signifikan ( $p>0,05)$, sehingga dapat disimpulkan bahwa harga diri tidak memilki pengaruh yang signifikan terhadap efiaksi guru MIN di kota Medan. Dengan demikian hipotesis keempat ditolak.

Hipotesis 5: Terdapat pengaruh signifikan efikasi guru terhadap pengembangan religiuisitas siswa MIN di kota Medan. Hasil analisis menunjukkan terdapat pengaruh efikasi guru terhadap pengembangan religiusitas siswa dengan beta yang cukup besar yaitu 0,762. Namun, sayangnya walaupun pengaruhnya besar, pengaruh tersebut tidaklah signifikan $(\mathrm{p}>0,05)$, sehingga dapat disimpulkan bahwa efikasi guru tidak memilki pengaruh yang signifikan terhadap pengembangan religiuisitas siswa MIN di kota Medan. Dengan demikian hipotesis kelima ditolak.

\section{Pembahasan}

Penelitian ini bertujuan untuk menginvestigasi faktor-faktor yaang berpengaruh terhadap efikasi guru dalam mengembangkan religiusitas siswa MIN yaitu kecerdasan emosional dan harga diri. Berdasarkan hasil analisis, ternyata kecerdasan emosional guru tidak mempengaruhi pengembangan religiusitas siswa secara signifikan. Berdasarkan data di atas, kecerdasan emosional adalah kemampuan merasakan, memahami, dan secara efektif menerapkan energi dan kepekaan emosional sebagai sumber energi, emosi, koneksi, dan pengaruh manusia. Individu yang mampu memahami emosi individu lain dapat berperilaku dan mengambil keputusan secara tepat tanpa menimbulkan dampak berbahaya bagi kedua belah pihak (Cobb \& Mayer, 2000). Namun, hal tersebut tidak dapat menjadi bukti bahwa kecerdasan emosi yang dimiliki guru mempengaruhi pengembangan religiusitas siswa secara signifikan. Hal ini didukung oleh penelitian yang dilakukan oleh (Fatchana, 2018) bahwa pengembangan religiusitas siswa yang diupayakan melalui sekolah tidak hanya berdasarkan tingkat keteladanan atau religiusitas dan kecerdasan emosi guru, namun harus diterapkan secara praktik dan dijadikan sebuah budaya dalam kegiatan pembelajaran di sekolah. Berbeda dengan Rasmini dan Karta (2021) yang menemukan bahwa pendidik atau guru justru dijadikan sebagai model bagi peserta didik yang kemudian diinternalisasikan ke dalam kode moral yang menentukan pikiran dan perilaku religius. Sehingga, guru dengan kecerdasan emosional yang tinggi akan mampu memberikan pengaruh yang tinggi pula terhadap pengembangan religiusitas siswanya.

Kemudian, hasil analisis yang menemukan bahwa harga diri guru mempengaruhi pengembangan religiusitas siswa MIN di kota Medan secara signifikan. Hal ini sejalan dengan penelitian yang dilakukan oleh (Surya, 2003) bahwa menjadi guru adalah harga diri. Harga 
diri seorang guru akan menjadi landasan bagi penampilannya sebagai guru secara tepat dan pada gilirannya akan berpengaruh terhadap seluruh siswa yang menjadi peserta didiknya termasuk dalam mengembangan karakter-karakter siswa yang positif dan religius. Muryanti dan Herman (2021) menambahkan bahwa guru dengan harga diri yang tinggi akan dapat berinovasi, mandiri, aktif, kreatif, dan inovatif dalam aktivitas pembelajaran, termasuk membangun karakter religius siswanya. Menurut Harga diri yang positif menurut (Mbuva, t.t.) akan menciptakan beberapa karakter positif. Beberapa diantaranya yaitu optimisme, memiliki kemampuan menyelesaikan masalah, dan sikap kooperatif. Sehingga, tidak menutup kemungkinan bahwa seorang guru dengan karakter-karakter tersebut secara signifikan mempengaruhi pengembangan religiusitas siswa. Dengan sikap optimis dan kooperatifnya, guru mampu mengembangkan karakter religiusitas siswanya.

Hasil analisis selanjutnya yaitu kecerdasan emosional tidak mempengaruhi efikasi guru secara signifikan. Hal ini bertentangan dengan penelitian yang dilakukan oleh (Julita dkk., 2019) yang menemukan bahwa kecerdasan emosional memiliki dampak positif secara langsung pada efikasi guru. Hal ini menunjukkan bahwa kecerdasan emosional merupakan aspek atau variabel penting yang perlu diupayakan peningkatannya. Kecerdasan emosional guru yang tinggi akan meningkatkan efikasi guru. Menurut (Herawaty, 2016), program pelatihan untuk meningkatkan kecerdasan emosional guru sangat diperlukan guna membuat kontribusi yang berharga, terutama kepercayaan pada kemampuan guru muda, guru lakilaki, dan guru yang memiliki status lebih rendah. Namun hal tersebut tidak sesuai dengan hasil analisis yang ditemukan oleh peneliti. Walaupun kecerdasan emosi guru dapat mempengaruhi efikasi guru dalam mengajar, namun pengaruh tersebut tidak dianggap signifikan. Senada dengan penemuan Nuranna (2019) bahwa kecerdasan emosional sangat penting dimiliki oleh seorang guru. Guru dengan kecerdasan emosional yang tinggi, akan dapat membangun kecerdasan emosional yang baik bagi siswanya. Namun, hal ini tidak berhubungan dengan efikasi diri yang dimiliki guru. Kecerdasan emosi mempengaruhi kinerja guru, tetapi tidak dengan efikasinya.

Setelah itu, hasil analisis yang menemukan bahwa harga diri tidak mempengaruhi efikasi guru secara signifikan. Hal ini bertentangan dengan penelitian yang dilakukan oleh (Huang dkk., 2007) yang menemukan bahwa semakin tinggi harga diri guru, maka semakin tinggi pula efikasi guru dalam mengajar. Namun, (Mbuva, t.t.) membuktikan bahwa harga diri guru dapat meningkatkan beberapa pengaruh pengajaran seperti pengembangan religiusitas, namun tidak dengan efikasinya. (Miller, t.t.) mengungkapkan bahwa harga diri guru mampu meningkatkan harga diri siswanya jika guru memiliki antusiasme dalam mengajar, sabar, memotivasi dan memberi tantangan pada siswanya dalam mengajar. Senada dengan penemuan Benevene, Ittan \& Cortin (2018) yang mengungkapkan bahwa guru dengan harga diri yang tinggi akan menciptakan kepuasan kerja yang tinggi. Demikian efikasi guru yang tinggi juga akan menciptakan kepuasan kerja yang tinggi pula. Namun, harga diri guru yang tinggi tidak mempengaruhi efikasinya secara signifikan.

Terakhir, hasil analisis yang menemukan bahwa efikasi guru tidak mempengaruhi pengembangan religiusitas siswa secara signifikan. Hal ini sejalan dengan penelitian yang dilakukan oleh (Bekomson \& Ntamu, 2019) bahwa efikasi guru yang tinggi tidak mempengaruhi tingginya pengembangan religiusitas siswa yang diajar. Ini dikarenakan, tidak cukup jika hanya guru yang melakukan pengembangan religiusitas siswanya, namun juga harus ada peran aktif orang tua untuk ikut melibatkan mereka dalam kegiatan dan diskusi keagamaan, sehingga mereka akan mampu membangun karakter religius dalam kehidupannya sehari-hari. Tarmilia \& Daliman (2021) juga mengungkapkan bahwa pengembangan religiusitas siswa menjadi sangat signifikan di tangan orang tuanya. Orang tua sebagai orang yang terdekat dengan siswa adalah pihak yang paling bertanggungjawab atas religiusitas anaknya. Religiusitas anak sangat dipengaruhi oleh ajaran orang tua (Trovão, 2017), guru, dan lingkungan (Sulaiman dkk., 2014) termasuk keluarga besar, masyarakat, serta teman. Sekolah dan rumah mempengaruhi perilaku religiusitas anak (Bano \& Ferra, 2018). 
Guru yang religius akan mengajarkan moral baik pada anak (Qoyyimah, 2016), sedangkan orang tua membimbing anak agar mampu menginternalisasi agama, yaitu anak memilih beribadah karena memahami dan senang, bukan karena dipaksa (Brambilla dkk., 2015).

Dalam pendidikan, figur manusia yang menempati posisi dan memegang peranan penting adalah seorang guru. Di sekolah, guru merupakan orang tua kedua bagi peserta didik. Di mata masyarakat, guru menempati kedudukan yang terhormat dan mendapat kepercayaan yang besar. Dengan kepercayaan tersebut, maka terdapat tanggung jawab di pundak guru. Tugas dan tanggung jawab guru tidak hanya sebatas dinding sekolah, tetapi juga di luar sekolah. Sehingga, kepribadian guru termasuk kecerdasan emosional dan harga dirinya dapat mempengaruhi suasana kelas dan perilaku siswanya.

Religiusitas merupakan bagian sentral dari kepribadian seseorang yang dapat dijadikan orientasi moral dan internalisasi nilai keimanan. Sehingga religiusitas ini tercermin dari cara seseorang berpikir dan bertindak. Pentingnya pengembangan religiusitas siswa dalam rangka menciptakan keharmonisan dalam kehidupan beragama dipengaruhi oleh beberapa faktor personal, yaitu kecerdasan emosi, harga diri dan efikasi guru.

Dengan menganalisis faktor-faktor yang berpengaruh terhadap efikasi guru dalam mengembangkan religiusitas siswanya, diharapkan ada perbaikan-perbaikan yang signifikan dari cara guru mendidik dan melakukan upaya pengembangan terhadap religiusitas siswa. sehingga, siswa sekolah sebagai generasi muda bangsa, dapat menjadi generasi yang religius, tidak merasa menjadi kelompok agama yang paing benar dan tidak menciptakan perpecahan antar umat beragama di masa depan.

\section{SIMPULAN}

Dari lima hipotesis penelitian, hanya satu hipotesis yang diterima berdasarkan data yang telah dianalisis, yaitu harga diri guru mempengaruhi pengembangan religiusitas siswa secara signifikan. Hal ini berarti bahwa semakin tinggi harga diri yang dimiliki guru, maka semakin tinggi pula upaya yang akan dilakukannya dalam mengembangkan religiusitas siswanya. Sementara keempat hipotesis yang lainnya ditolak. Bahwa kecerdasan emosi mempengaruhi pengembangan religiusitas siswa dan efikasi guru namun tidak secara signifikan. Demikian harga diri yang mempengaruhi efikasi guru dan efikasi guru yang mempengaruhi pengembangan religiusitas siswa tidak secara signifikan. Upaya pengembangan religiusitas anak tidak hanya menjadi tanggungjawab guru, tetapi juga orang tua, dan lingkungan.

\section{UCAPAN TERIMA KASIH}

Kami sampaikan terima kasih kepada Kepala Sekolah Madrasah Ibtidaiyah Negeri (MIN) di kota Medan yang telah mengijinkan penulis untuk melakukan penelitian dan kepada para guru MIN dan pihak-pihak yang tidak bisa kami sebutkan satu persatu.

\section{DAFTAR PUSTAKA}

Anindyajati, M., \& Karima, C. M. (2004). Peran Harga Diri Terhadap Asertivitas Remaja Penyalahguna Narkoba. Universitas Esa Unggul, 2(1), $25 .$.

Bada, S.O. \& Hassan L,J. (2021). Effect of teachers' self-esteem on students' academic performance in secondary schools in Jibia local government area of Katsina State.Nigerian Online Journal of Educational Sciences and Technology (NOJEST), 3(2), Pages 31-36

Bano, M., \& Ferra, E. (2018). Family Versus School Effect On Individual Religiosity : Evidence From Pakistan. International Journal of Educational Development, 59(December 2016), 35-42. https:// doi.org/10.1016/j.ijedudev.2017.10.015 
Bekomson, A. N., \& Ntamu, B. A. (2019). Religious value orientation and self-efficacy among secondary school students in cross River State, Nigeria. Global Journal of Educational Research, 18(2), 81. https://doi.org/10.4314/gjedr.v18i2.4

Benevene, P. Ittan, M. \& Cortin, M. (2018). Self-Esteem and Happiness as Predictors of School Teachers' Health: The Mediating Role of Job Satisfaction. Front. Psychol., 17 July 2018 | https://doi.org/10.3389/fpsyg.2018.00933

Brambilla, M., Assor, A., Manzi, C., Regalia, C., \& Brambilla, M. (2015). Autonomous Versus Controlled Religiosity : Family and Group Antecedents Autonomous Versus Controlled Religiosity : Family and Group Antecedents. The International Journal for the Psychology of Religion, 193-210. https:// doi.org/10.1080/10508619.2014.888902

Damayanti, M. E. (2020). Pengaruh Self Esteem Terhadap Self Efficacy Pada Siswa [Skripsi]. Universitas Muhammadiyah Malang.

Darmadi. (2020). Pengaruh Kecerdasan Emosional Diri Dan Prestasi Terhadap Efikasi Guru Yang Dimoderasi Budaya Organisasi (Studi Kasus Pada Guru SMP Negeri di Kecamatan Juwana Kabupaten Pati). Universitas Stikubank Semarang.

Dewi, S. S. (2021). Efikasi Guru dalam Mengembangkan Pendiidkan Karakter Siswa SDIT di Sumatera Utara. Yogyakarta [Thesis (S1), Universitas Muhammadiyah Yogyakarta]. https://etd.umy.ac.id/id/eprint/4997

Earnshaw, E. L. (t.t.). Religious Orientation and Meaning in Life: An Exploratory Study. 9.

Erawati, M. (2012). Profil Dan Faktor-Faktor Yang Memengaruhi Efikasi Guru Madrasah Ibtidaiyah Peserta Dual Mode System. Inferensi, 6(2), 417. https://doi.org/10.18326/infsl3.v6i2.417-440

Fahyuni, E. F., \& Istikomah. (2016). Psikologi Belajar \& Mengajar: Kunci Sukses Gurur dan Peserta Didik dalam Interaksi Edukatif. Nizamia Learning Centre.

Fatchana, D. T. (2018). Peningkatan religiusitas siswa melalui budaya sekolah. Pascasarjana Universitas Islam Negeri Sunan Ampel Surabaya. 190.

Ghufron, M. N. (2012). Kepercayaan tentang Hakekat Pengetahuan dan bagaimana Mengetahui Perspektif Psikologi. Penerbit Idea Press.

Guskey, T. R., \& Passaro, P. D. (t.t.). Teacher Efficacy: A Study of Construct Dimensions. 17.

Hasanah, H., \& Fadlilah, A. (2018). Problem Religiusitas dan Coping Spiritual pada Anak Berhadapan Hukum. Sawwa: Jurnal Studi Gender, 13(1), 67-84. https:// doi.org/10.21580/sa.v13i1.2474

Herawaty, D. (2016). Pengaruh Kecerdasan Emosional, Partisipasi Guru dalam Forum Ilmiah, Keyakinan Diri (Self Efficacy), dan Motivasi Kerja Terhadap Kinerja Guru Matematika. Jurnal Review Pembelajaran Matematika, 1(1), 71-85. https://doi.org/10.15642/jrpm.2016.1.1.71-85

Houkamau, C., Stronge, S., Warbrick, I., Dell, K., Mika, J., Newth, J., Sibley, C., \& Kha, K. L. (2021). Cultural efficacy predicts body satisfaction for Māori. PLOS ONE, 16(6), e0253426. https:// doi.org/10.1371/journal.pone.0253426

Huang, X., Liu, M., \& Shiomi, K. (2007). An Analysis Of The Relationships Between Teacher Efficacy, Teacher Self-Esteem And Orientations To Seeking Help. Social Behavior and Personality: An International Journal, 35(5), 707-716. https://doi.org/10.2224/sbp.2007.35.5.707

Jennett, H. K., Harris, S. L., \& Mesibov, G. B. (2003). Commitment to Philosophy, Teacher Efficacy, and Burnout Among Teachers of Children with Autism. Journal of Autism and Developmental Disorders, 33(6), 583-593. https://doi.org/10.1023/B:JADD.0000005996.19417.57

Julita, S., Herawaty, D., \& Gusri, S. A. (2019). Pengaruh Kecerdasan Emosional, Dan Self Efficacy Terhadap Kinerja Guru Matematika. JUPITEK: Jurnal Pendidikan Matematika, 2(1), 31-34. https://doi.org/10.30598/jupitekvol2iss1pp31-34 
Mbuva, J. (t.t.). Exploring Teachers' Self-Esteem and Its Effects on Teaching, Students' Learning and Self-Esteem. 10.

Miller, P. (t.t.). Ten Characteristics of a Good Teacher. $\mathrm{N} \mathrm{u} \mathrm{m} \mathrm{b} \mathrm{e} \mathrm{r,} 3$.

Muryanti, E. \& Herman, Y. (2021). Studi Perbandingan Sistem Pendidikan Dasar di Indonesia dan Finlandia. Vol.ume 6 Issue 2 (2022) Pages 1146-1156 Jurnal Obsesi : Jurnal Pendidikan Anak Usia Dini. https:/ / doi.org/10.31004/obsesi.v6i3.1696

Ningsih, K. A, Prasetyo, I \& Hasanah. (2022). Pendidikan Karakter Anak Usia Dini melalui Sentra Bahan Alam. Volume 6 Issue 3 (2022) Pages 1093-1104 Jurnal Obsesi: Jurnal Pendidikan Anak Usia Dini. https:/ / doi.org/10.31004/obsesi.v6i3.1172

Nuranna. (2019). Korelasi antara Kecerdasan Emosional Guru dengan Kinerja Guru Pendidikan Agama Islam (Pai) SMA Di Gowa. UIN Alauddin Makassar

Oktiva, N. (2021). Pentingnya Kecerdasan Emosional Bagi Guru. https://akupintar.id/infopintar/-/blogs/pentingnya-kecerdasan-emosional-bagi-guru

Qoyyimah, U. (2016). Inculcating Character Education Through EFL Teaching In Indonesian State Schools Indonesian State Schools. Pedagogies: An International Journal ISSN:, 118. https:// doi.org/10.1080/1554480X.2016.1165618

Rasmini, N. W \& Karta, I. W. (2021). Analysis of the Impact of Storytelling Methods on Early Childhood Religion and Moral Development. Volume 6 Issue 3 (2022) Pages 1147-1157 Jurnal Obsesi : Jurnal Pendidikan Anak Usia Dini. https://doi.org/10.31004/obsesi.v6i3.1719

Sugiyono. (2011). Metode Penelitian Kuantitatif, Kualitatif dan R\&D. Afabeta.

Sulaiman, A., Jamsari, E. A., \& Noh, N. C. (2014). Islamic Environment in Child Development According to the Views of Imam al-Ghazali. Mediterranean Journal of Social Sciences, 5(29), 33-39. https:// doi.org/10.5901/mjss.2014.v5n29p33

Surya, M. (2003). Psikologi Guru konsep dan aplikasi Guru untuk Guru. Afabeta.

Tarmilia \& Daliman. (2021). Model Percakapan untuk Menanamkan Religiusitas Ibadah dari Orang Tua ke Anak. Volume 6 Issue 3 (2022) Pages 1080-1092 Jurnal Obsesi : Jurnal Pendidikan Anak Usia Dini. https:/ / doi.org/10.31004/obsesi.v6i3.1664

Trovão, S. S. (2017). Parental Transmission of Religion and Citizenship among Migrant Muslim Families in Mozambique, Portugal , United Kingdom and Angola. Journal of Muslim Minority Affairs, 37(2), 129-146. https:/ / doi.org/10.1080/13602004.2017.1345102

Tschannen-Moran, M., \& Hoy, A. W. (2001). Teacher efficacy: Capturing an elusive construct. Teaching and Teacher Education, 17(7), 783-805. https://doi.org/10.1016/S0742051X(01)00036-1

Umar, M. (2019). Urgensi Nilai-Nilai Religius Dalam Kehidupan Masyarakat Heterogen Di Indonesia. Jurnal Civic Education: Media Kajian Pancasila dan Kewarganegaraan, 3(1), 71. https:/ / doi.org/10.36412/ce.v3i1.909

Yunus, F. M. (2014). Konflik Agama Di Indonesia Problem Dan Solusi Pemecahannya. Substantia: Jurnal Ilmu-Ilmu Ushuluddin, 16(12) ttp://dx.doi.org/10.22373/substantia.v16i2.4930 